\title{
Answer to the Letter to the Editor concerning "4- and 5-level anterior fusions of the cervical spine"
}

\author{
O. Meier $\cdot$ A. Hempfing $\cdot$ H. Koller
}

Published online: 12 July 2008

(C) Springer-Verlag 2008

Erratum to: Eur Spine J

DOI 10.1007/s00586-008-0697-7

An error has occurred in the affiliations of the authors.

The address for all authors is:

Werner-Wicker-Clinic Bad Wildungen

German Scoliosis Center

Im Kreuzfeld 4

34537 Bad Wildungen

Germany

The online version of the original article can be found under doi:10.1007/s00586-008-0697-7.

O. Meier · A. Hempfing $\cdot$ H. Koller $(\bowtie)$

Werner-Wicker-Clinic Bad Wildungen,

German Scoliosis Center, Im Kreuzfeld 4,

34537 Bad Wildungen, Germany

e-mail: heiko.koller@t-online.de 